\title{
Respiratory Syncytial Virus Infection is Associated with Increased Bacterial Load in the Upper Respiratory Tract in Young Children
}

\section{Chappell KJ ${ }^{1,2 *}$, Brealey $\mathrm{JC}^{1}$, Mackay $\mathrm{IM}^{1,3}$, Bletchly $\mathrm{C}^{4}$, Hugenholtz $\mathrm{P}^{1,5,7}$, Sloots $\mathrm{TP}^{3}$, Sly $\mathrm{PD}^{6}$ and Young $\mathrm{PR}^{1,2,7 *}$}

${ }^{1}$ Australian Infectious Diseases Research Centre, the University of Queensland, Australia

${ }^{2}$ School of Chemistry and Molecular Biosciences, the University of Queensland, Australia

${ }^{3}$ Queensland paediatric infectious diseases laboratory, The Sir Albert Sakzewski Virus Research Centre, Queensland Children's Medical Research Institute, The

University of Queensland, Australia

${ }^{4}$ Pathology Queensland Central, Royal Brisbane and Women's Hospital, Queensland, Australia

${ }^{5}$ Australian Centre for Ecogenomics, School of Chemistry and Molecular Biosciences, the University of Queensland, Australia

${ }^{6}$ Queensland Children's Medical Research Institute, the University of Queensland, Australia

${ }^{7}$ Institute for Molecular Bioscience, the University of Queensland, Australia

\begin{abstract}
Background: Respiratory syncytial virus (RSV) is the leading cause of severe respiratory tract infection requiring hospitalization among infants and young children. Furthermore, RSV infection has been shown to stimulate increased bacterial load in the nasopharynx and to promote bacterial otitis media and/or pneumonia.

Objective: To assess the diversity and prevalence of bacterial pathogens associated with viral infections of the respiratory tract among young children.

Study design: During the 2012 seasonal RSV epidemic in South East Queensland, Australia, 201 nasopharyngeal aspirates (NPAs) collected from symptomatic children under five years of age and sent for pathology laboratory screening were examined. Samples were analysed for common viral and bacterial pathogens by quantitative PCR and culturing techniques. For a subset of 29 samples the complete microbial community was profiled using cultureindependent PCR and pyrosequencing of the 165 ribosomal RNA gene.

Results: RSV infection was confirmed in 67 patients, of which 49 were positive for high bacterial load in the upper respiratory tract. Bacterial detection was significantly higher amongst RSV positive samples (73.1\%) than amongst RSV negative samples $(56.7 \%)(p=0.03)$ and was independent of other viral pathogens. The predominant bacterial species detected during RSV infections were Moraxella catarrhalis (22), Streptococcus pneumoniae (17), Haemophilus influenzae (5) and Staphylococcus aureus (6). Notably, microbial profiling analysis showed that during either RSV or rhinovirus infections a single bacterial species can constitute between 80 and $95 \%$ of the bacterial community present.
\end{abstract}

Conclusions: In nasopharyngeal samples collected from symptomatic children, high levels of bacteria were found more commonly in the presence of RSV infections. Most significantly, RSV infection was associated with a 3-fold increase in S. pneumoniae detection.

Keywords: Respiratory syncytial virus; Streptococcus Pneumoniae; Paediatric respiratory infection; Co-infection

Abbreviations: ARIs: Acute Respiratory Infections; HAdV: Human Adenovirus; hMPV: Human Metapneumovirus; HRV: Human Rhinovirus; IFAV/IFBV: Influenza Virus A/B; NPAs: Nasopharyngeal Aspirates; PICU: Paediatric Intensive Care Unit; PIV1-3: Parainfluenza Virus 1-3; PQC: Pathology Queensland Central; QIIME: Quantitative Insights Into Microbial Ecology; RSV: Respiratory Syncytial Virus; UPGMA: Unweighted Pair Group Method with Arithmetric Mean

\section{Introduction}

Respiratory viral infections that affect the lower respiratory tract during early childhood are often associated with secondary bacterial infections including Streptococcus pneumoniae, Haemophilus influenzae, Moraxella catarrhalis and Staphylococcus aureus [1,2]. While colonization with these bacterial species is common during childhood and often independent of symptoms $[3,4]$, respiratory viral infections have been shown to stimulate a substantial increase in bacterial load that can lead to bacterial otitis media or pneumonia [5-9].

Globally, Respiratory Syncytial Virus (RSV) is the leading cause of severe Acute Respiratory Infections (ARIs) requiring hospitalization among infants and young children. RSV infects over $90 \%$ of children by the age of two and causes cold-like symptoms that frequently progress to lower respiratory disease such as bronchiolitis and pneumonia [10]. Approximately $0.5 \%$ of RSV infections require hospitalization [11], with RSV estimated to be responsible for 3 million hospitalizations and 200,000 deaths annually [10]. RSV is known to be associated with bacterial co-infections of the upper and lower respiratory tract $[1,2,12$ 18], however it remains unclear whether a correlation exists between bacterial co-infection and RSV disease severity. While a number of

*Corresponding authors: Keith Chappell, Australian Infectious Diseases Research Centre, School of Chemistry and Molecular Bioscience, University of Queensland, St Lucia, Queensland 4072, Australia, E-mail: k.chappell@uq.edu.au

Paul Young, Australian Infectious Diseases Research Centre, School of Chemistry and Molecular Bioscience, University of Queensland, St Lucia, Queensland 4072, Australia, E-mail: p.young@uq.edu.au

Received April 14, 2013; Accepted July 01, 2013; Published July 05, 2013

Citation: Chappell KJ, Brealey JC, Mackay IM, Bletchly C, Hugenholtz P, et al. (2013) Respiratory Syncytial Virus Infection is Associated with Increased Bacterial Load in the Upper Respiratory Tract in Young Children. J Medical Microbiol Diagnosis S1: 005. doi:10.4172/2161-0703.S1-005

Copyright: (c) 2013 Chappell KJ, et al. This is an open-access article distributed under the terms of the Creative Commons Attribution License, which permits unrestricted use, distribution, and reproduction in any medium, provided the original author and source are credited. 
Citation: Chappell KJ, Brealey JC, Mackay IM, Bletchly C, Hugenholtz P, et al. (2013) Respiratory Syncytial Virus Infection is Associated with Increased Bacterial Load in the Upper Respiratory Tract in Young Children. J Medical Microbiol Diagnosis S1: 005. doi:10.4172/2161-0703. S1-005

Page 2 of 9

studies have failed to find any correlation with severity [16,19], others have shown that patients with RSV/bacterial co-infections are more likely to be admitted to a Paediatric Intensive Care Unit (PICU) [20] and of patients admitted to the PICU, those with RSV/bacterial coinfection require ventilator support for longer than those with RSV alone $[1,17]$.

Previous reports attempting to define the prevalence of viral/ bacterial co-infections during ARI and pneumonia have produced varying estimates (23-66\%) [1,2,8,12-18,21,22]. While differences are to be expected, given the numerous environmental factors including differences in populations, geographic locations and seasonality that are likely to play a role, a large percentage of this variation may also be attributed to differences in sample collection, screening methods and the classification used to define positive samples.

Most studies conducted to date have focused solely on the detection of a handful of common pathogens through targeted PCR screening or detection of those that are amenable to culture. Such approaches to bacterial identification are not ideal as disease-associated species may not readily grow in culture and thus be excluded from individual analyses, while culturable but less relevant agents may be included. Targeted approaches often result in a significant proportion $(\sim 25 \%)$ of samples testing negative for both bacterial and viral pathogens despite clear ARI symptoms $[9,18,21]$. The failure to quantify bacterial load in addition to presence/absence can also complicate differentiation between commensal carriage and increased bacterial load that may contribute to pathogenesis and ultimately to appropriate decisions about individual patient management. Consequently, current detection rates for viral/bacterial co-infections may either substantially under- or over-estimate the true situation.

The development of culture-independent, molecular approaches for the study of microbial communities provides the opportunity to investigate microbial diversity without limiting analysis to those species which are able to be cultivated in the laboratory. Techniques such as deep sequencing of $16 \mathrm{~S}$ ribosomal RNA genes are able to reveal far greater microbial diversity than culture-based studies [23], although such techniques are still limited by their inability to differentiate beyond the family or genus level to the level of individual species. Several studies have used culture-independent techniques to characterize the microbiota of the respiratory tract, in various states of health and disease including chronic lung diseases, such as Cystic Fibrosis [24-26] and Chronic Obstructive Pulmonary Disease [27-29] as well as acute respiratory infections [30-32]. To date, there appear to be no studies in the literature specifically examining both viral carriage and microbiota composition in paediatric ARIs.

\section{Objectives}

The aim of this study was to examine the prevalence of viral/ bacterial co-infections of the respiratory tract during early childhood and to identify associations between individual viruses and bacterial pathogens. To achieve this aim we conducted a detailed analysis of 201 Nasopharyngeal Aspirates (NPAs) sent for pathology laboratory screening and collected from children under the age of five with ARI symptoms. Samples were screened for common respiratory viral infections by real-time PCR (rtPCR) and for bacteria amenable to detection via culturing methods. In order to directly compare the information obtained through culture-independent vs dependent screening, a subset of 29 samples was screened by culture-independent pyrosequencing of the $16 \mathrm{~S}$ rRNA gene to provide a less biased profile of the bacterial communities present in the nasopharynx during ARI.

\section{Materials and Methods}

\section{Study population}

We accessed 201 NPAs from children under the age of five that were sent to Pathology Queensland Central (PQC) at the Royal Brisbane and Women's Hospital for routine screening of respiratory virus presence. These samples were collected in clinical settings from hospitals in South East of Queensland, Australia over an eight week period spanning the seasonal RSV epidemic, from late March to mid May 2012. NPAs were mixed with glycerol to a final concentration of $25 \%$ and stored at $-80^{\circ} \mathrm{C}$. Samples were de-identified with information of patient sex and date of birth being accessible. This study was approved by the Children's Health Services Queensland Human Research Ethics Committee, HREC reference number: HREC/12/QRCH/196.

\section{Viral testing}

All 201 samples were tested by Queensland Health Pathology Services (QHPS) for RSV, parainfluenzavirus-1,-2,-3 (PIV1-3), influenza virus A and B, Human Adenovirus (HAdV) and Human Metapneumovirus (hMPV) via rtPCR as per QHPS routine procedures. NPAs were either extracted neat or diluted in VTM if the volume was low. $200 \mu \mathrm{L}$ was extracted on either the MagNAPure (Roche) or the $\mathrm{X}$-tractorGene (Qiagen) using a total nucleic acid extraction kit and eluted in $100 \mu \mathrm{L}$. Real-time PCR assays were performed by combining extracts with appropriate mastermix into 96 well plates and run on an $\mathrm{ABI} 7500$ instrument using the cycling conditions: $50^{\circ} \mathrm{C}$ for 20 minutes ( 1 cycle), $95^{\circ} \mathrm{C}$ for 15 minutes ( 1 cycle), $95^{\circ} \mathrm{C}$ for $15 \mathrm{sec}$ and $60^{\circ} \mathrm{C}$ for 60 $\sec (45$ cycles) [33-36]. Additionally, the presence of human rhinovirus (HRV) was detected via real-time RT-PCR as previously reported [37].

\section{Culture-dependent bacterial testing}

Each sample $(10 \mu \mathrm{l})$ was spread onto a $5 \%$ blood agar plate with an optochin disk to allow the presumptive identification of S. pneumoniae and a $5 \%$ chocolate agar plate with an $\mathrm{X}+\mathrm{V}$ Factor disk to allow the presumptive identification of $H$. influenzae and incubated overnight at $37^{\circ} \mathrm{C}$. Only plates with greater than 100 colonies (i.e. over 10,000 colony forming units $(\mathrm{cfu}) / \mathrm{ml})$ with conserved morphological features were considered as positive for bacterial growth. Representative colonies were then characterized by $16 \mathrm{~S}$ rRNA gene sequencing. Briefly, bacterial cells were lysed by suspending 1-2 colonies in $100 \mu \mathrm{l}$ of water and boiling for 5 mins prior to PCR amplification and sequencing of the 16S rRNA gene with primers 27F (5'AGAGTTTGATCCTGGCTCAG) and 514R (5'CCGCGRCTGCTGGCAC).

\section{Community profiling}

Total DNA was extracted from a subset of 29 samples using either the PureLink Genomic DNA Purification Kit (Life technologies Invitrogen division) or the High Pure Viral Nucleic Acid Isolation Kit (Roche) as per the manufacturer's instructions. The overall concentration of DNA extracted from each sample was quantified by measuring absorbance at $260 \mathrm{~nm}$, while quantitative PCR of the $16 \mathrm{~S}$ rRNA gene was used to estimate the microbial load for each sample. Quantitative PCR used primers 1406F (5'GYACWCACCGCCCGT) and 1525R (5'AAGGAGGTGWTCCARCC). To identify organisms present in each sample, 454 pyrosequencing of the $16 \mathrm{~S}$ rRNA gene was 
Citation: Chappell KJ, Brealey JC, Mackay IM, Bletchly C, Hugenholtz P, et al. (2013) Respiratory Syncytial Virus Infection is Associated with Increased Bacterial Load in the Upper Respiratory Tract in Young Children. J Medical Microbiol Diagnosis S1: 005. doi:10.4172/2161-0703. S1-005

Page 3 of 9

performed. For sequencing, copies of the $16 \mathrm{~S}$ rRNA gene present in each sample were amplified with the primers $803 \mathrm{~F}$ and $1392 \mathrm{R}$ containing the 454 adaptors [38]. Each reverse primer contained a unique barcode sequence (5-8 bp in length) to allow the identification of each sample during the multiplex sequencing process. A two-step PCR process was used to maximize PCR product [39]. In the first step, $50 \mu \mathrm{lPCR}$ reactions were performed using $10 \mu \mathrm{l}$ of extracted DNA with $25 \mu \mathrm{l}$ of MyTaq HS Mix (Bioline, Sydney) and $1 \mu \mathrm{l}$ each of $10 \mu \mathrm{M}$ native $803 \mathrm{~F}$ and $1392 \mathrm{R}$ primers. In the second round of PCR, $2 \mu \mathrm{l}$ of the product from the first step was used as template in 10 -cycle $50 \mu \mathrm{PCR}$ reactions, using the barcoded, pyrosequencing versions of the $803 \mathrm{~F}$ and $1392 \mathrm{R}$ primers. Amplified DNA was then sequenced at the Australian Centre for Ecogenomics using 454 GS-FLX Titanium pyrosequencing.

Reads were trimmed to $350 \mathrm{bp}$ and those under this length or of low quality were removed. Chimeric sequences were removed via UCLUST [40] and homopolymer sequencing errors were corrected via Acacia [41]. Quantitative Insights into Microbial Ecology (QIIME) was used to select operational taxonomic units (OTUs) [42], with a UCLUST cluster similarity threshold of $97 \%$. OTU taxonomy was then assigned using BLAST with the Greengenes database $[40,43,44]$ and the read counts normalized across the 29 samples. OTUs that were not identified in the Greengenes database were searched against the GenBank NR (nonredundant) database and non-specific amplifications of host DNA were removed.

Measures of alpha diversity were calculated, to assess richness (number of species) and evenness (relative abundance of species) of the microbial community within each sample. These metrics included rarefaction curves of the observed number of species, Shannon indices, Simpson indices and Chaol estimates. Average Shannon indices, Simpson indices and Chaol estimates for each cohort were calculated at 650 sequences per sample, since the minimum number of reads for any sample was 665 .

\section{Statistical Analysis}

Fisher's exact test was used to analyse the statistical significance of the results, using a two-sided alternative hypothesis. Contingency tables were built to compare viral and bacterial infection categories. Odds ratios were calculated to assess the strength of various associations and are reported along with $95 \%$ confidence intervals.

\section{Results}

\section{Viral detection}

A total of 201 samples were collected from children under the age of five years with a median age of 9.3 months. 153 samples $(76.1 \%)$ were positive for at least one common respiratory virus with up to three viruses detected in individual samples. RSV was the most common virus identified among children less than six months old (RSV 31.3\%; HRV 19.3\%), while HRV was the most common among children between 6 months and 5 years of age (HRV 35.6\%; RSV 19.5\%) (Table 1).

\section{Bacterial detection}

Of 201 samples 126 (62.7\%) were defined as positive for bacterial colonization, under criteria used to differentiate between high level bacterial colonization $(>10,000 \mathrm{cfu} / \mathrm{ml})$ and normal, low level growth of nasal microbiota in the respiratory tract. The most common bacteria identified by culture-based methods were $M$. catarrhalis in 54 samples (26.9\%), S. pneumoniae in 28 samples (13.9\%), S. aureus in 23 samples

\begin{tabular}{|c|c|c|c|c|c|}
\hline & $\begin{array}{l}0-6 \\
\text { months }\end{array}$ & $\begin{array}{l}6-12 \\
\text { months }\end{array}$ & $\begin{array}{l}12-24 \\
\text { months }\end{array}$ & $\begin{array}{l}24-60 \\
\text { months }\end{array}$ & Total \\
\hline Number of samples & 83 & 41 & 36 & 41 & 201 \\
\hline Viral positive & $53(73.9)$ & $35(85.4)$ & $31(86.1)$ & $34(82.9)$ & $153(76.1)$ \\
\hline RSV & $26(31.3)$ & $12(29.3)$ & 4 (11.1) & $7(17.1)$ & $49(24.4)$ \\
\hline RSV+HAdV & 0 & 0 & $1(2.8)$ & 0 & $1(0.5)$ \\
\hline RSV+HRV & $3(3.6)$ & $4(9.8)$ & $3(8.3)$ & $3(7.3)$ & $13(6.5)$ \\
\hline RSV+IFAV & 0 & 0 & 0 & $1(2.4)$ & $1(0.5)$ \\
\hline RSV+HRV+IFAV & 0 & $1(2.4)$ & 0 & 0 & $1(0.5)$ \\
\hline RSV+PIV2 & 0 & 0 & $1(2.8)$ & 0 & $1(0.5)$ \\
\hline RSV+PIV3+HAdV & 0 & 0 & 0 & $1(2.4)$ & $1(0.5)$ \\
\hline HRV & $16(19.3)$ & $12(29.3)$ & $15(41.7)$ & $15(36.6)$ & $58(28.9)$ \\
\hline HRV+PIV1 & $4(4.8)$ & 0 & 0 & $1(2.4)$ & $5(2.5)$ \\
\hline HRV+PIV2 & $1(1.2)$ & 0 & 0 & 0 & $1(0.5)$ \\
\hline HRV+HAdV & 0 & $3(7.3)$ & $4(11.1)$ & 0 & $7(3.9)$ \\
\hline HRV+HAdV+IFAV & 0 & 0 & $1(2.8)$ & 0 & $1(0.5)$ \\
\hline PIV1 & $2(2.4)$ & $1(2.4)$ & $1(2.8)$ & $3(7.3)$ & $7(3.5)$ \\
\hline PIV2 & $1(1.2)$ & $1(2.4)$ & 0 & $2(4.9)$ & $4(2.0)$ \\
\hline HAdV & 0 & 0 & $1(2.8)$ & $1(2.4)$ & $2(1.0)$ \\
\hline IFAV & 0 & $1(2.4)$ & 0 & 0 & $1(0.5)$ \\
\hline Viral negative & $30(36.1)$ & $6(14.6)$ & 5 (13.9) & 7 (17.1) & $48(23.9)$ \\
\hline Total RSV & $29(34.9)$ & $17(41.5)$ & $9(25.0)$ & $12(29.3)$ & 67 (33.3) \\
\hline Total HRV & $24(28.9)$ & $20(48.8)$ & $23(63.9)$ & $19(46.3)$ & $86(42.8)$ \\
\hline Total PIV & $8(9.6)$ & $2(4.9)$ & $2(5.6)$ & 7 (17.1) & $19(9.5)$ \\
\hline Total HAdV & NA & $3(7.3)$ & 7 (19.4) & $2(4.9)$ & $12(6.0)$ \\
\hline
\end{tabular}

Table 1: Viral detection: Number of cases (percentage).

\begin{tabular}{|l|l|l|l|l|l|}
\hline & $\begin{array}{l}\mathbf{0 - 6} \\
\text { months }\end{array}$ & $\begin{array}{l}\mathbf{6 - 1 2} \\
\text { months }\end{array}$ & $\begin{array}{l}\mathbf{1 2 - 2 4} \\
\text { months }\end{array}$ & $\begin{array}{l}\mathbf{2 4 - 6 0} \\
\text { months }\end{array}$ & Total \\
\hline Number of samples & 83 & 41 & 36 & 41 & 201 \\
\hline Bacterial positive & $57(68.7)$ & $27(65.8)$ & $27(75.0)$ & $15(36.6)$ & $126(62.7)$ \\
\hline M. catarrhalis & $21(25.3)$ & $16(39.0)$ & $11(30.6)$ & $6(14.6)$ & $54(26.9)$ \\
\hline S. pneumoniae & $8(9.6)$ & $7(17.1)$ & $8(22.2)$ & $5(12.2)$ & $28(13.9)$ \\
\hline S. aureus & $15(18.7)$ & $1(2.4)$ & $3(8.3)$ & $2(4.9)$ & $23(11.4)$ \\
\hline H. influenzae & $3(3.6)$ & $1(2.4)$ & $4(11.1)$ & $1(2.2)$ & $9(4.5)$ \\
\hline Other* & $23(27.7)$ & $9(22.0)$ & $8(22.2)$ & $4(9.8)$ & $44(21.9)$ \\
\hline Bacterial negative & $26(31.3)$ & $14(34.2)$ & $9(25.0)$ & $26(63.4)$ & $75(37.3)$ \\
\hline 1 bacteria & $36(43.4)$ & $19(46.3)$ & $19(52.8)$ & $11(26.8)$ & $85(42.3)$ \\
\hline 2 or more bacteria & $21(25.3)$ & $8(19.5)$ & $8(25.0)$ & $4(9.8)$ & $41(20.4)$ \\
\hline
\end{tabular}

*includes: Klebsiella spp., Bacillus spp., Neisseria spp., Haemophilus spp., Rothia spp., S. mitis, S. dysgalactiae, S. haemolyticus, S. epidermidis, S. Iugdunensis, S. warneri, M. nonliquefaciens, Stenotrophomonas spp., Enterococcus faecalis, Gammaproteobacteria spp., Hafnia alvei, Obesumbacterium spp., Serratia marcescens, Enterobacter spp., Acinetobacter calcoaceticus and E. coli.

Table 2: Bacterial detection: Number of cases (percentage).

(11.4\%) and $H$. influenzae in nine samples (4.5\%) (Table 2). Other species that were each identified in less than four individual samples, include Klebsiella spp., Bacillus spp., Neisseria spp., Haemophilus spp., Rothia spp., Streptococcus mitis, Streptococcus dysgalactiae, Staphylococcus haemolyticus, Staphylococcus epidermidis, Staphylococcus lugdunensis, Staphylococcus warneri, Moraxella nonliquefaciens, Stenotrophomonas spp., Enterococcus faecalis, Gammaproteobacteria spp., Hafnia alvei, Obesumbacterium spp., Serratia marcescens, Enterobacter spp., Acinetobacter calcoaceticus and Escherichia coli. The identity of eight bacterial isolates forming colonies failed to be determined as the $16 \mathrm{~S}$ rRNA gene primers used did not result in product amplification.

M. catarrhalis were the most common colonising bacteria identified in all age groups, with colonization rates peaking at 39\% between 6 to 12 months. Colonization with $S$. aureus was most common among the 0-6 months age group and dropped dramatically in children over six months of age, while colonization with S. pneumoniae and 
Citation: Chappell KJ, Brealey JC, Mackay IM, Bletchly C, Hugenholtz P, et al. (2013) Respiratory Syncytial Virus Infection is Associated with Increased Bacterial Load in the Upper Respiratory Tract in Young Children. J Medical Microbiol Diagnosis S1: 005. doi:10.4172/2161-0703. S1-005

Page 4 of 9

\begin{tabular}{|c|c|c|c|c|c|c|c|c|c|c|c|c|c|c|c|}
\hline & \multicolumn{3}{|c|}{$0-6$ months } & \multicolumn{3}{|c|}{ 6-12 months } & \multicolumn{3}{|c|}{ 12-24 months } & \multicolumn{3}{|c|}{ 24-60 months } & \multicolumn{3}{|c|}{ Total } \\
\hline & RSV & HRV & neg & RSV & HRV & Neg & RSV & HRV & Neg & RSV & HRV & Neg & RSV & HRV & neg \\
\hline Number of samples & 26 & 17 & 30 & 12 & 12 & 6 & 4 & 15 & 5 & 7 & 14 & 7 & 49 & 58 & 48 \\
\hline Bacterial positive & $19(73.1)$ & $13(76.5)$ & $19(63.3)$ & $11(91.7)$ & 7 (58.3) & $2(33.3)$ & $4(100)$ & $10(66.7)$ & $3(60.0)$ & $4(57.1)$ & $5(35.7)$ & $2(28.6)$ & $38(77.5)$ & $35(60.3)$ & $26(54.2)$ \\
\hline S. pneumoniae & $3(11.5)$ & 0 & $3(10.0)$ & $5(41.6)$ & $1(8.3)$ & 0 & $3(75.0)$ & $1(6.7)$ & 0 & $1(14.3)$ & $2(14.3)$ & $1(14.2)$ & $12(24.5)$ & $4(6.9)$ & $4(8.3)$ \\
\hline H. influenzae & $2(7.6)$ & 0 & $1(3.3)$ & $1(8.3)$ & 0 & 0 & $1(25.0)$ & $2(13.3)$ & $1(20.0)$ & $1(14.3)$ & 0 & 0 & $5(10.2)$ & $2(3.4)$ & $2(4.2)$ \\
\hline M. catarrhalis & $8(30.7)$ & $6(35.2)$ & $6(20.0)$ & $6(50.0)$ & 4 (33.3) & $1(16.7)$ & $1(25.0)$ & $4(26.7)$ & $1(20.0)$ & $2(28.6)$ & $2(14.3)$ & 0 & $17(34.7)$ & $16(27.6)$ & $8(16.7)$ \\
\hline S. aureus & $3(11.5)$ & $4(23.5)$ & $6(20.0)$ & $1(8.3)$ & 0 & 0 & 0 & $1(6.7)$ & $1(20.0)$ & $1(14.3)$ & $1(7.1)$ & 0 & $6(12.2)$ & $6(10.3)$ & $8(16.7)$ \\
\hline Other & $8(30.7)$ & $4(23.5)$ & $10(33.3)$ & $3(25.0)$ & $4(33.3)$ & $1(16.7)$ & $1(25.0)$ & $5(33.3)$ & $1(20.0)$ & 0 & $1(7.1)$ & $2(28.6)$ & $12(24.4)$ & $14(24.1)$ & $14(29.2)$ \\
\hline Bacterial negative & $7(26.9)$ & $4(23.5)$ & $11(36.7)$ & $1(8.3)$ & $5(41.7)$ & $4(66.7)$ & 0 & $5(33.3)$ & $2(40.0)$ & $3(42.9)$ & $9(64.3)$ & $5(71.4)$ & $11(22.5)$ & $23(39.7)$ & $22(45.8)$ \\
\hline
\end{tabular}

Table 3: Viral/bacterial co-detection: Number of cases (percentage).

\begin{tabular}{|l|l|l|l|l|}
\hline & $\begin{array}{l}\text { RSV pos } \\
\text { (67 samples) }\end{array}$ & $\begin{array}{l}\text { RSV neg } \\
\text { (134 samples) }\end{array}$ & Odds ratio & $\mathbf{9 5 \%} \mathbf{C l}$ \\
\hline Any bacteria & $49(73.1)$ & $76(56.7)$ & 2.08 & $1.10-3.94$ \\
\hline M. catarrhalis & $22(32.8)$ & $32(23.9)$ & 1.56 & $0.82-2.97$ \\
\hline S. pneumoniae & $17(25.4)$ & $11(8.2)$ & 3.80 & $1.67-8.69$ \\
\hline S. aureus & $6(9.0)$ & $17(12.7)$ & 0.68 & $0.25-1.81$ \\
\hline H. influenzae & $5(7.5)$ & $4(3.0)$ & 2.62 & $0.68-10.10$ \\
\hline Other & $13(19.4)$ & $31(23.1)$ & 0.80 & $0.39-1.65$ \\
\hline
\end{tabular}

Table 4: Bacteria associated with RSV infection (all age groups): Number of cases (percentage).

\begin{tabular}{|l|l|l|l|l|}
\hline & $\begin{array}{l}\text { RSV pos } \\
\text { (26 samples) }\end{array}$ & $\begin{array}{l}\text { RSV neg } \\
\text { (51 samples) }\end{array}$ & Odds ratio & 95\% CI \\
\hline Any bacteria & $23(88.5)$ & $31(60.8)$ & 4.95 & $1.31-18.66$ \\
\hline M. catarrhalis & $12(46.2)$ & $15(29.4)$ & 2.06 & $0.77-5.47$ \\
\hline S. pneumoniae & $10(38.5)$ & $5(9.8)$ & 5.75 & $1.71-19.38$ \\
\hline S. aureus & $1(3.8)$ & $3(5.9)$ & 0.64 & $0.06-6.48$ \\
\hline H. influenzae & $2(7.7)$ & $3(5.9)$ & 1.33 & $0.21-8.52$ \\
\hline Other & $5(19.2)$ & $12(23.5)$ & 0.77 & $0.24-2.49$ \\
\hline
\end{tabular}

Table 5: Bacteria associated with RSV infection (6-24 months): Number of cases (percentage).

$H$. influenzae peaked in the 12-24 month age group. Children under the age of two were approximately twice as likely to be positive for high bacterial colonization as those over two $(69.4 \%$ vs $36.6 \%$; $=0.0001)$.

In 85 samples (42.3\%) a single bacterial species was identified while in 41 samples $(20.4 \%)$ two or more species of bacteria were present. No significant positive associations between the detection of bacterial species were identified, however we found a negative association between $S$. pneumoniae and $S$. aureus, as these were never detected in the same sample $(\mathrm{p}=0.050)$, a finding that has been previously reported [45-49] (Table 2).

\section{Viral/bacterial co-detection}

Potential viral and bacterial pathogens were detected together in 100 samples (49.8\%), while virus alone was detected in 53 samples (26.4\%) and bacteria alone in 26 samples (12.9\%). No potential pathogens were identified in 22 samples (10.9\%), which was lower than for previous studies $[9,14,18,21,50]$. Detection of any virus was not significantly associated with bacterial detection. $65.4 \%$ of virus-positive samples were also positive for bacteria, while $54.2 \%$ of virus-negative samples were positive for bacteria $(\mathrm{p}=0.17)$. Furthermore, the presence of multiple viral pathogens did not affect bacterial detection, with $65.3 \%$ of single viral infections and $65.6 \%$ of multiple viral infections positive for the co-detection of bacteria.

When comparing individual viral infections (Table 3) it is apparent that RSV is associated with bacterial detection; $77.5 \%$ of single RSV infections were associated with bacterial detection compared with
$60.3 \%$ of single HRV infections and $54.2 \%$ of viral negative samples ( $\mathrm{p}=0.057$ and 0.019 , respectively). Most significantly, single RSV infection was associated with S. pneumoniae detection, with $24.5 \%$ of RSV infections positive for S. pneumoniae compared to $6.9 \%$ of HRV and $8.3 \%$ of virus negative samples ( $\mathrm{p}=0.014$ and 0.053 ). The association between RSV infection and bacterial detection was most striking in children between the ages of six months and two years (Table 3). RSV was also associated with an increase in $M$. catarrhalis and $H$. influenzae detection compared to HRV and virus-negative samples, however the trend was not significant ( $\mathrm{p}=0.53$ and 0.06 for $M$. catarrhalis, and $\mathrm{p}=0.24$ and 0.44 for $H$. influenzae) (Table 3).

Taking into account all samples positive for RSV, the odds ratio of bacterial co-detection is 2.08 (95\% CI=1.10-3.94), when compared to all samples negative for RSV, irrespective of other viral pathogens. Bacterial co-infection was detected in 49 of 67 RSV positive samples (73.1\%), compared with 51 of 86 (59.3\%) of other viral infections and 26 of $48(54.2 \%)$ of viral negative samples. One or more of the four most commonly detected bacteria (M. catarrhalis, S. pneumoniae, $H$. influenzae and S. aureus) were found in 40 of 67 (59.7\%) RSV infections and 56 of 134 (41.8\%) samples that was negative for RSV.

The odds ratio for bacterial detection increased to 4.95 (95\% CI $=1.31$ 18.66) between the ages of six months and two years. Within this age range, 23 of $26 \mathrm{RSV}$ positive samples $(88.5 \%)$ were positive for bacteria, most notably $M$. catarrhalis ( 12 of 26 samples, $46.2 \%$ ) and S. pneumoniae (10 of 26, 38.5\%). The odds ratio for S. pneumoniae detection associated with RSV infection was calculated to be $3.80(95 \% \mathrm{CI}=1.67-8.69)$ for all children under 5 and 5.75 (95\%CI=1.71-19.38) for children aged between 6 and 24 months (Tables 4 and 5).

\section{Microbial community profiling}

To assess changes in the microbiota of the nasopharynx induced by viral infection, 29 samples were selected at random from each of three sample groups based on viral detection (10 RSV-positive, $10 \mathrm{HRV}$ positive and 9 virus-negative samples). Sequencing was successful in all cases with between 665 and 15783 reads for each sample (mean: 5397). Relative abundances of the most frequent bacterial families identified in each sample group are shown in Figure 1, while the individual taxa contributing greater than $5 \%$ of the microbial community in each sample are shown in Table 6.

Microbial diversity is a measure of both community richness (the number of different species present) and evenness (the relative abundance of each species). Alpha diversity, the microbial community variation within each sample, demonstrated that the depth of sequencing was not sufficient to identify all members of the microbial community. Samples varied greatly in alpha diversity measurements, masking the presence of any significant trends associated with each cohort (Supplementary Figure 1). 
Citation: Chappell KJ, Brealey JC, Mackay IM, Bletchly C, Hugenholtz P, et al. (2013) Respiratory Syncytial Virus Infection is Associated with Increased Bacterial Load in the Upper Respiratory Tract in Young Children. J Medical Microbiol Diagnosis S1: 005. doi:10.4172/2161-0703. S1-005

Page 5 of 9

\begin{tabular}{|c|c|c|c|c|c|}
\hline \multicolumn{2}{|l|}{ Patient } & \multirow{2}{*}{\begin{tabular}{|l|} 
Age \\
1 month
\end{tabular}} & \multirow{2}{*}{\begin{tabular}{|l|} 
Culture-dependant screen \\
Gammaproteobacteria
\end{tabular}} & \multirow{2}{*}{\begin{tabular}{|l|} 
Taxa contributing to $>5 \%$ of microbiota \\
Staphylococcus $(77.67)$
\end{tabular}} & \multirow{2}{*}{\begin{tabular}{|l|} 
Microbial biomass $(\mathrm{ng} / \mu \mathrm{l})$ \\
338.77
\end{tabular}} \\
\hline \multirow{10}{*}{ RSV positive } & 0540 & & & & \\
\hline & 8213 & 2 months & Negative & $\begin{array}{l}\text { Enterobacteriaceae (50.67) } \\
\text { Leclercia }(45.50)\end{array}$ & 0.51 \\
\hline & 2921 & 2 months & Klebsiella sp & $\begin{array}{l}\text { Prevotella }(28.83) \\
\text { Haemophilus }(22.67) \\
\text { Stenotrophomonas }(12.17) \\
\text { Streptococcus }(11.67)\end{array}$ & 0.29 \\
\hline & 9636 & 4 months & Negative & $\begin{array}{l}\text { Haemophilus (48.67) } \\
\text { Flavobacteriaceae }(17.83) \\
\text { Diaphorobacter }(7.50)\end{array}$ & 0.41 \\
\hline & 0908 & 9 months & M. catarrhalis & Moraxella (92.33) & 13.98 \\
\hline & 1002 & 11 months & S. aureus & $\begin{array}{l}\text { Streptococcus }(54.00) \\
\text { Veillonella }(11.50) \\
\text { Gemella }(9.00)\end{array}$ & 0.87 \\
\hline & 5582 & 1 year & S. pneumoniae $+M$. catarrhalis & Streptococcus (93.50) & 18.86 \\
\hline & 9851 & $\begin{array}{l}2 \text { years, } \\
9 \text { months }\end{array}$ & S. pneumoniae+E. faecalis & $\begin{array}{l}\text { Neisseria (18.67) } \\
\text { Pseudomonas }(17.17) \\
\text { Enterococcus }(14.00) \\
\text { Streptococcus }(11.00) \\
\text { Fusobacterium }(5.50) \\
\text { Stenotrophomonas }(5.00)\end{array}$ & 0.84 \\
\hline & 5149 & $\begin{array}{l}2 \text { years } \\
9 \text { months }\end{array}$ & M. catarrhalis + Klebsiella $\mathrm{sp}$ & Moraxella (87.33) & 26.06 \\
\hline & 4323 & 3 years & M. catarrhalis & $\begin{array}{l}\text { Moraxella }(39.83) \\
\text { Enterobacteriaceae (28.83) } \\
\text { Leclercia }(23.00)\end{array}$ & 2.83 \\
\hline \multirow{10}{*}{ HRV positive } & 4543 & 3 months & Negative & $\begin{array}{l}\text { Stenotrophomonas }(30.83) \\
\text { Flavobacteriaceae }(26.17) \\
\text { Diaphorobacter }(11.17) \\
\text { Idiomarinaceae }(8.50)\end{array}$ & 0.27 \\
\hline & 4362 & 4 months & S. aureus & Staphylococcus (94.67) & 136.37 \\
\hline & 6594 & 6 months & S. aureus+S. mitis & $\begin{array}{l}\text { Streptococcus (54.33) } \\
\text { Gemella (11.67) } \\
\text { Prevotella (5.83) }\end{array}$ & 1.86 \\
\hline & 3456 & 7 months & Negative & $\begin{array}{l}\text { Flavobacteriaceae }(24.33) \\
\text { Stenotrophomonas }(15.67) \\
\text { Diaphorobacter }(14.83) \\
\text { Moraxella }(14.00) \\
\text { Idiomarinaceae }(12.33)\end{array}$ & 0.46 \\
\hline & 3374 & 7 months & S. pneumoniae $+M$. catarrhalis & $\begin{array}{l}\text { Streptococcus (65.17) } \\
\text { Moraxella (21.83) }\end{array}$ & 1.68 \\
\hline & 9428 & 10 months & M. catarrhalis & Moraxella (81.67) & 52.63 \\
\hline & 3066 & $\begin{array}{l}1 \text { year, } \\
8 \text { months }\end{array}$ & E. coli & Carnobacteriaceae (80.33) & 0.85 \\
\hline & 2144 & $\begin{array}{l}1 \text { year, } \\
11 \text { months }\end{array}$ & M. catarrhalis & Moraxella (93.33) & 236.36 \\
\hline & 4308 & $\begin{array}{l}2 \text { years, } \\
10 \text { months }\end{array}$ & S. dysgalactiae+Rothia $\mathrm{sp}$ & $\begin{array}{l}\text { Neisseria }(54.50) \\
\text { Haemophilus }(9.83) \\
\text { Fusobacterium }(8.17)\end{array}$ & 32.72 \\
\hline & 2110 & 3 years & Negative & $\begin{array}{l}\text { Flavobacteriaceae }(19.67) \\
\text { Stenotrophomonas }(17.17) \\
\text { Staphylococcus }(14.50) \\
\text { Diaphorobacter }(13.33) \\
\text { Idiomarinaceae }(7.67)\end{array}$ & 0.44 \\
\hline \multirow{9}{*}{ Virus-negative } & 5110 & 1 month & Negative & $\begin{array}{l}\text { Haemophilus }(33.00) \\
\text { Staphylococcus }(30.50) \\
\text { Streptococcus }(24.17)\end{array}$ & 3.56 \\
\hline & 9905 & 1 month & Negative & $\begin{array}{l}\text { Streptococcus (65.67) } \\
\text { Prevotella (15.67) }\end{array}$ & 0.71 \\
\hline & 7569 & 1 month & S. pneumoniae $+M$. catarrhalis & $\begin{array}{l}\text { Streptococcus (49.00) } \\
\text { Moraxella }(29.33)\end{array}$ & 6.67 \\
\hline & 8664 & 2 months & S. aureus & Corynebacterium (95.50) & 3.74 \\
\hline & 9360 & 2 months & Enterobacter sp & Leclercia (89.33) & 159.64 \\
\hline & 0734 & 2 months & S. maltophilia & Acinetobacter (84.17) & 5.89 \\
\hline & 1742 & 4 months & Negative & Moraxella (89.33) & 34.16 \\
\hline & 1276 & $\begin{array}{l}1 \text { year, } \\
4 \text { months }\end{array}$ & Negative & Streptococcus (71.00) & 0.46 \\
\hline & 5784 & $\begin{array}{l}4 \text { years, } \\
5 \text { months }\end{array}$ & S. aureus & $\begin{array}{l}\text { Staphylococcus }(40.17) \\
\text { Carnobacteriaceae }(28.17) \\
\text { Streptococcus }(12.00)\end{array}$ & 3.19 \\
\hline
\end{tabular}

Table 6: Comparison of culture dependent-screen and microbiota analysis. 
Citation: Chappell KJ, Brealey JC, Mackay IM, Bletchly C, Hugenholtz P, et al. (2013) Respiratory Syncytial Virus Infection is Associated with Increased Bacterial Load in the Upper Respiratory Tract in Young Children. J Medical Microbiol Diagnosis S1: 005. doi:10.4172/2161-0703. S1-005

Page 6 of 9

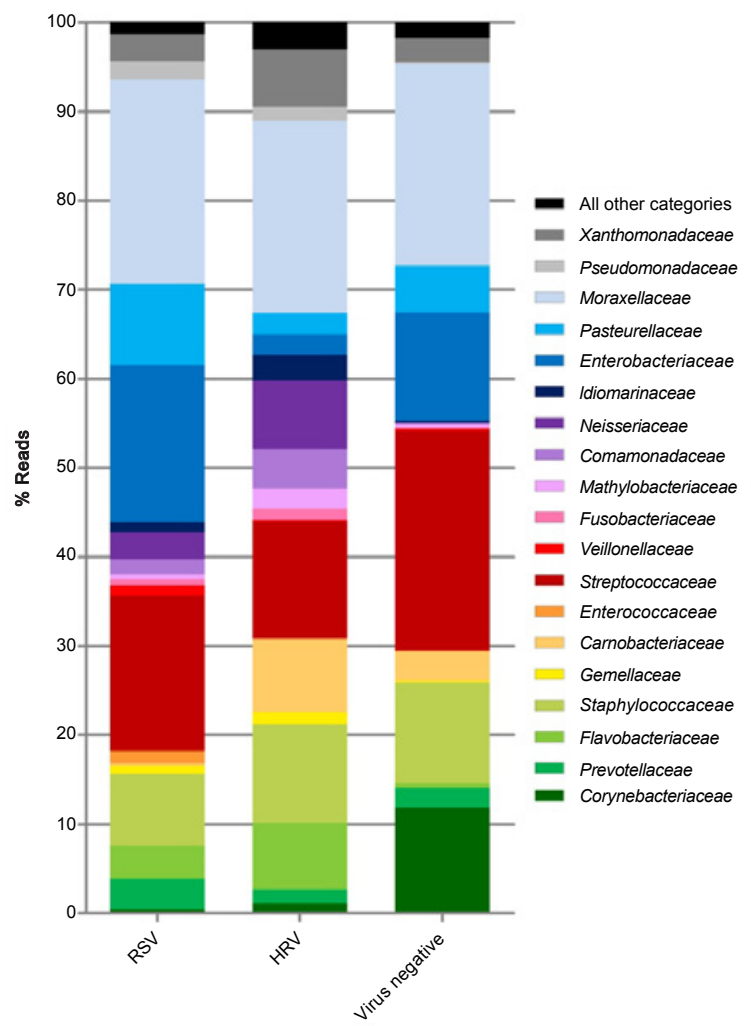

Figure 1: Relative abundances of the most frequent bacterial families identified in RSV positive, HRV positive and virus negative samples. Families with relative abundances $>0.1 \%$ in at least one cohort are shown. All other families are grouped under "All other categories".

Bacteria from the bacterial families Streptococcaceae, Moraxellaceae, Staphylococcaceae, Enterobacteriaceae, Pasteurellaceae, Prevotellaceae and Xanthomonadaceae were frequent across RSV positive, HRVpositive and virus-negative samples (Figure 1). Neisseriaceae, Gemellacae and Fusobacteriaceae families were commonly associated with viruspositive samples, while bacteria from the Micrococcaceae family were present in virus-negative samples. Corynebacteriaceae were dominant in virus-negative samples, although the family was present in viruspositive samples as well. In contrast, a greater percentage of bacteria in virus positive samples were accounted for by Flavobacteriaceae, Comamonadaceae, Idiomarinaceae and Pseudomonadaceae species. Enterococcaceae were specific to RSV-positive samples, Veillonellaceae were common to RSV-positive and virus-negative samples and Carnobacteriaceae were shared between HRV-positive and virusnegative samples.

Reflecting the community profiling results at the family level, several bacterial genera were common to all three cohorts, including Moraxella, Staphylococcus, Streptococcus, Haemophilus, Corynebacterium, Prevotella, Leclercia, Stenotrophomonas and Pseudomonas (Table 6). Neisseria was almost exclusively in virus-positive samples. Unspecified Idiomarinaceae species were observed in all three cohorts, always in association with Diaphorobacter, Pseudomonas and Stenotrophomonas, although these three genera also occurred independently.

Table 6 shows the major taxa contributing to the microbial community. Of particular note are three RSV positive samples, three HRV positive samples and one virus-negative sample in which Moraxella, Streptococcus or Staphylococcus were found to represent between 80 to $90 \%$ of the bacteria present in the nasopharynx. In each of these samples the total microbial biomass was approximately 10 -fold higher than the median value for all 29 samples (Table 6).

\section{Comparison between culturing and community profiling results}

Comparison between the culture-dependent and -independent screens is limited by the inability to differentiate taxa to the level of species in the community profiles. Table 6 provides a comparison between the culture-dependent and -independent screens for the individual samples. Overall the correlation between the two screens with regard to detection of the most widely recognized pathogenic genera, Streptococcus, Moraxella, Haemophilus and Staphylococcus, was fair. However, as expected, the culture-independent microbiota analysis was both more sensitive for the detection of bacteria amenable to culturing and for detection of genera that were unable to be cultured. The culture-independent screen identified Streptococcus (in six samples), Moraxella (in two samples), Haemophilus (in three samples) and Staphylococcus (in three samples) that were either not detected or produced less than the defined cut off at $10,000 \mathrm{cfu} / \mathrm{ml}$ in the culture-dependent screen. It also should be stressed that in these instances identified genera do not necessarily correlate with the species amenable to culture identified in other samples. Additionally in some instances (samples 2921, 6594, 3066) bacteria producing greater than $10,000 \mathrm{cfu} / \mathrm{ml}$ were shown to constitute only a small fraction of the total microbial biomass while in other instances (samples 9636, 1276) bacteria producing less than $10,000 \mathrm{cfu} / \mathrm{ml}$ were constituted a high proportion of the microbial biomass.

\section{Discussion}

Globally, RSV is the leading cause of severe respiratory tract infections requiring hospitalization during early childhood. Various studies have now shown that RSV infection is often associated with bacterial co-infection $[1,2,12-18]$. Our results show that approximately $75 \%$ of RSV infections are associated with a high load of potentially pathogenic bacteria in the nasopharynx (greater than $10,000 \mathrm{cfu} / \mathrm{ml}$ of NPA). This proportion of RSV/bacterial co-detection was significantly higher than for other viral infections and virus-negative samples. The prevalence of bacterial detection associated with RSV was found to peak among children aged between six and 24 months with close to $90 \%$ testing positive for high bacterial presence.

The most common bacteria associated with RSV were $M$. catarrhalis (32.8\%), S. pneumoniae (25.4\%) and H. influenzae (7.5\%). One or more of these three pathogens were found in $55 \%$ of all RSV infections and $73 \%$ of RSV infections in children between the ages of six and 24 months. While RSV was shown to be associated with increased bacterial prevalence when compared to other acute respiratory infections amongst the same age group, unfortunately samples from healthy children were not available for direct comparison or from samples outside of the "RSV season". It has previously been shown that the colonization rates for such bacteria among healthy children are high (M. catarrhalis: $22-36 \%$, S. pneumoniae: $17-38 \%$, H. influenzae: $12-$ $32 \%)$, and comparable to those determined by this study in association with RSV infection [4,47,49,51-53]. However, differences in the methods of sample collection, culturing and the definition of bacterial load considered positive mean that direct comparison between our results and those of healthy children is difficult.

Previous studies attempting to determine prevalence of bacterial co-infection associated with RSV infection have produced estimates varying between $16 \%$ and $55 \%[1,2,9,12,14-18,21,50]$. The majority of these studies examined bacteria within samples collected from the lower respiratory tract or measured circulating antibodies to respiratory bacteria. Brunstein et al. [18] was the only other study to focus on the detection of bacteria in the upper airways. A comparable 
Citation: Chappell KJ, Brealey JC, Mackay IM, Bletchly C, Hugenholtz P, et al. (2013) Respiratory Syncytial Virus Infection is Associated with Increased Bacterial Load in the Upper Respiratory Tract in Young Children. J Medical Microbiol Diagnosis S1: 005. doi:10.4172/2161-0703. S1-005

level of bacterial prevalence associated with RSV infection was found for S. pneumoniae (17.3\%) and H. influenzae (11.4\%), however other bacteria of interest were not examined.

The viral and culture-dependent bacterial screens we have employed in this study provided increased power in determining a presumptive causative agent compared to previous studies. Only 22 of $201(10.9 \%)$ samples were negative for both viral and bacterial pathogens, compared to typically around $25 \%$ of samples tested by previous studies which have employed methods that limit their scope by focusing solely on specific pathogens $[9,18,21,50]$.

The use of the culture-independent microbiota analysis can further increase the ability to detect the presence of potentially pathogenic bacteria that are unable to be cultured using routine methods, e.g. Flavobacteriaceae, Idiomarinaceae, Comamonadaceae, Neisseria and Pseudomonas. We found that virus-positive samples more frequently contained higher relative abundances of Flavobacteriaceae and Comamonadaceae, which have been detected previously in viruspositive NPAs [32], and Neisseria and Pseudomonas, which have been detected in lower respiratory tract infections $[30,31,54]$. While Flavobacteriaceae and Neisseria species have also been detected in the healthy nasopharynx [55], Comamonadaceae have, rarely, been found in human chronic lung conditions [56,57]. Idiomarinaceae were also present more frequently in virus-positive samples. This family contains Gram-negative, aerobic organisms that are usually isolated from saline habitats and to our knowledge have not been previously reported in human infections. Their presence in virus-positive samples from paediatric ARIs is surprising and warrants further investigation. Since the majority of the Idiomarinaceae reads were from an unclassified genus, their presence could be suggestive of a novel human-associated phylotype.

The use of culture-independent microbiota analysis was found to be more sensitive than the culture-dependent screen as a number of samples harbored species of bacteria that in theory should have been detected by bacterial culture. In some of these cases bacteria were present but below the limit of $10,000 \mathrm{cfu} / \mathrm{ml}$ set for positive detection. Discrepancies between the results of the culture-dependent and -independent screens highlight the inherent difficulty in detection of bacteria through culture-dependent methods. In some instances species were shown to constitute a considerable percentage of total bacterial biomass but failed to be identified in the culture dependent screen. The reliance on live bacterial isolates for identification is presumably a major obstacle affecting the culture-dependent screen. Bacterial lysis initiated by the host's immune response or antibiotic use may affect bacterial viability. Additionally storage of samples at $-80^{\circ} \mathrm{C}$ in $25 \%$ glycerol may have reduced bacterial viability in some instances. By coupling the larger culture-dependent screen with a more focused culture-independent screen we were able to put together a more comprehensive understanding of the specific effect of viral infection on bacterial communities within the nasopharynx. Strikingly, community profiling data revealed that in 4 of 10 RSV infections, as well as 3 of $10 \mathrm{HRV}$ infections, an individual bacterial genus constituted between 75 and $95 \%$ of the total bacterial population of the nasopharynx. The species identified were $M$. catarrhalis, S. pneumoniae and S. aureus in the case of RSV and M. catarrhalis and S. aureus in the case of HRV. Furthermore, the total bacterial load in these samples estimated by rtPCR was substantially higher than for other samples suggesting that a large growth of these individual species accompanied viral infection as has been previously suggested [58-63]. The substantial changes to the flora of the nasopharynx accompanying viral infection should be further investigated as such changes would be likely to affect the induction of a targeted immune response, contribute to the presentation of symptoms and severity and increase the likelihood of progression to secondary bacterial pneumonia or otitis media.
The clinical significance of these findings is an important question that cannot be addressed by the present study as we did not have access to clinical information. Previously it has been suggested patients with RSV/bacterial co-infections were more likely to be admitted to the PICU [20] and to require ventilatory support for longer than those with only RSV $[1,17,20]$.

The strikingly high prevalence of RSV/bacterial co-infections, along with the potential for such bacteria to proliferate to the point of constituting up to $95 \%$ of the total bacterial community during viral infection, highlights the possibility that RSV infection could conceivably facilitate bacterial transmission and colonization of new hosts. As both RSV and common bacterial pathogens of the respiratory tract are transmitted through direct contact with nasal secretions, it appears logical that both may therefore be expelled and subsequently acquired together by new hosts [64]. In support of this hypothesis it has been shown that infection with influenza virus is able to enhance both susceptibility and efficient transmission of $S$. pneumoniae in animal models [65-68]. While our study has highlighted an association between RSV and bacterial pathogens in the nasopharynx of young children in a clinical setting, a prospective study will be required to understand the clinical significance of this observation.

\section{Acknowledgements}

We thank the Australian Infectious Diseases Research Centre for research support awarded to Young P and Sly P, Pathology Queensland Central for the provision of clinical specimens and Nancy Lachner and Josh Daly for assistance with the rtPCR.

\section{References}

1. Thorburn K, Harigopal S, Reddy V, Taylor N, van Saene HK (2006) High incidence of pulmonary bacterial co-infection in children with severe respiratory syncytial virus (RSV) bronchiolitis. Thorax 61: 611-615.

2. Hishiki H, Ishiwada N, Fukasawa C, Abe K, Hoshino T, et al. (2011) Incidence of bacterial coinfection with respiratory syncytial virus bronchopulmonary infection in pediatric inpatients. J Infect Chemother 17: 87-90.

3. Korona-Glowniak I, Niedzielski A, Malm A (2011) Upper respiratory colonization by Streptococcus pneumoniae in healthy pre-school children in south-east Poland. Int J Pediatr Otorhinolaryngol 75: 1529-1534.

4. Bogaert D, van Belkum A, Sluijter M, Luijendijk A, de Groot R, et al. (2004) Colonisation by Streptococcus pneumoniae and Staphylococcus aureus in healthy children. Lancet 363: 1871-1872.

5. Bogaert D, De Groot R, Hermans PW (2004) Streptococcus pneumoniae colonisation: the key to pneumococcal disease. Lancet Infect Dis 4: 144-154.

6. Casey JR, Adlowitz DG, Pichichero ME (2010) New patterns in the otopathogens causing acute otitis media six to eight years after introduction of pneumococcal conjugate vaccine. Pediatr Infect Dis J 29: 304-309.

7. Pettigrew MM, Gent JF, Pyles RB, Miller AL, Nokso-Koivisto J, et al. (2011) Viralbacterial interactions and risk of acute otitis media complicating upper respiratory tract infection. J Clin Microbiol 49: 3750-3755.

8. Honkinen M, Lahti E, Österback R, Ruuskanen O, Waris M (2012) Viruses and bacteria in sputum samples of children with community-acquired pneumonia. Clin Microbiol Infect 18: 300-307.

9. Vu HT, Yoshida LM, Suzuki M, Nguyen HA, Nguyen CD, et al. (2011) Association between nasopharyngeal load of Streptococcus pneumoniae, viral coinfection, and radiologically confirmed pneumonia in Vietnamese children. Pediatr Infect Dis J 30: 11-18.

10. Nair H, Nokes DJ, Gessner BD, Dherani M, Madhi SA, et al. (2010) Global burden of acute lower respiratory infections due to respiratory syncytial virus in young children: a systematic review and meta-analysis. Lancet 375: 1545-1555.

11. Collins PL, Graham BS (2008) Viral and host factors in human respiratory syncytial virus pathogenesis. J Virol 82: 2040-2055

12. Korppi M, Leinonen M, Koskela M, Mäkelä PH, Launiala K (1989) Bacteria 
Citation: Chappell KJ, Brealey JC, Mackay IM, Bletchly C, Hugenholtz P, et al. (2013) Respiratory Syncytial Virus Infection is Associated with Increased Bacterial Load in the Upper Respiratory Tract in Young Children. J Medical Microbiol Diagnosis S1: 005. doi:10.4172/2161-0703. S1-005

coinfection in children hospitalized with respiratory syncytial virus infections. Pediatr Infect Dis J 8: 687-692.

13. La Via WV, Grant SW, Stutman HR, Marks MI (1993) Clinical profile of pediatric patients hospitalized with respiratory syncytial virus infection. Clin Pediatr (Phila) 32: $450-454$

14. Juvén T, Mertsola J, Waris M, Leinonen M, Meurman O, et al. (2000) Etiology of community-acquired pneumonia in 254 hospitalized children. Pediatr Infect Dis J 19: 293-298

15. Randolph AG, Reder L, Englund JA (2004) Risk of bacterial infection in previously healthy respiratory syncytial virus-infected young children admitted to the intensive care unit. Pediatr Infect Dis J 23: 990-994.

16. Duttweiler L, Nadal D, Frey B (2004) Pulmonary and systemic bacterial coinfections in severe RSV bronchiolitis. Arch Dis Child 89: 1155-1157.

17. Kneyber MC, Blusse van Oud-Alblas H, van Vliet M, Uiterwaal CS, Kimpen JL, et al. (2005) Concurrent bacterial infection and prolonged mechanical ventilation in infants with respiratory syncytial virus lower respiratory tract disease. Intensive Care Med 31:680-685.

18. Brunstein JD, Cline CL, McKinney S, Thomas E (2008) Evidence from multiplex molecular assays for complex multipathogen interactions in acute respiratory infections. J Clin Microbiol 46: 97-102.

19. Nuolivirta K, Koponen P, He Q, Halkosalo A, Korppi M, et al. (2010) Bordetella pertussis infection is common in nonvaccinated infants admitted for bronchiolitis. Pediatr Infect Dis J 29: 1013-1015.

20. Resch B, Gusenleitner W, Mueller WD (2007) Risk of concurrent bacterial infection in preterm infants hospitalized due to respiratory syncytial virus infection. Acta Paediatr 96: 495-498.

21. De Schutter I, De Wachter E, Crokaert F, Verhaegen J, Soetens O, et al. (2011) Microbiology of bronchoalveolar lavage fluid in children with acute nonresponding or recurrent community-acquired pneumonia: identification of nontypeable Haemophilus influenzae as a major pathogen. Clin Infect Dis 52: 1437-1444.

22. Cilla G, Oñate E, Perez-Yarza EG, Montes M, Vicente D, et al. (2008) Viruses in community-acquired pneumonia in children aged less than 3 years old: High rate of viral coinfection. J Med Virol 80: 1843-1849.

23. Pace NR (1997) A molecular view of microbial diversity and the biosphere. Science 276: 734-740.

24. Zhao J, Schloss PD, Kalikin LM, Carmody LA, Foster BK, et al. (2012) Decadelong bacterial community dynamics in cystic fibrosis airways. Proc Natl Acad Sci U S A 109: 5809-5814.

25. Delhaes L, Monchy S, Fréalle E, Hubans C, Salleron J, et al. (2012) The airway microbiota in cystic fibrosis: a complex fungal and bacterial community-implications for therapeutic management. PLoS One 7: e36313.

26. van der Gast CJ, Walker AW, Stressmann FA, Rogers GB, Scott P, et al. (2011) Partitioning core and satellite taxa from within cystic fibrosis lung bacterial communities. ISME J 5: 780-791.

27. Erb-Downward JR, Thompson DL, Han MK, Freeman CM, McCloskey L, et al (2011) Analysis of the lung microbiome in the "healthy" smoker and in COPD. PLoS One 6: e16384.

28. Cabrera-Rubio R, Garcia-Núñez M, Setó L, Antó JM, Moya A, et al. (2012) Microbiome diversity in the bronchial tracts of patients with chronic obstructive pulmonary disease. J Clin Microbiol 50: 3562-3568.

29. Huang YJ, Kim E, Cox MJ, Brodie EL, Brown R, et al. (2010) A persistent and diverse airway microbiota present during chronic obstructive pulmonary disease exacerbations. OMICS 14: 9-59.

30. Zhou Y, Lin P, Li Q, Han L, Zheng H, et al. (2010) Analysis of the microbiota of sputum samples from patients with lower respiratory tract infections. Acta Biochim Biophys Sin (Shanghai) 42: 754-761.

31. Bousbia S, Papazian L, Saux P, Forel JM, Auffray JP, et al. (2012) Repertoire of intensive care unit pneumonia microbiota. PLoS One 7: e32486.

32. Lysholm F, Wetterbom A, Lindau C, Darban H, Bjerkner A, et al. (2012) Characterization of the viral microbiome in patients with severe lower respiratory tract infections, using metagenomic sequencing. PLoS One 7: e30875.
33. Whiley DM, Syrmis MW, Mackay IM, Sloots TP (2002) Detection of human respiratory syncytial virus in respiratory samples by LightCycler reverse transcriptase PCR. J Clin Microbiol 40: 4418-4422.

34. Whiley DM, Sloots TP (2005) A 5'-nuclease real-time reverse transcriptasepolymerase chain reaction assay for the detection of a broad range of influenza $A$ subtypes, including H5N1. Diagn Microbiol Infect Dis 53: 335-337.

35. Lambert SB, Whiley DM, O'Neill NT, Andrews EC, Canavan FM, et al. (2008) Comparing nose-throat swabs and nasopharyngeal aspirates collected from children with symptoms for respiratory virus identification using real-time polymerase chain reaction. Pediatrics 122:e615-620.

36. O'Grady KA, Torzillo PJ, Rockett RJ, Whiley DM, Nissen MD, et al. (2011) Successful application of a simple specimen transport method for the conduct of respiratory virus surveillance in remote Indigenous communities in Australia. Trop Med Int Health 16: 766-772.

37. Mackay IM, Lambert SB, Faux CE, Arden KE, Nissen MD, et al. (2013) Community-wide, contemporaneous circulation of a broad spectrum of human rhinoviruses in healthy Australian preschool-aged children during a 12-month period. J Infect Dis 207: 1433-1441.

38. Engelbrektson A, Kunin V, Wrighton KC, Zvenigorodsky N, Chen F, et al. (2010) Experimental factors affecting PCR-based estimates of microbial species richness and evenness. ISME J 4: 642-647.

39. Berry D, Ben Mahfoudh K, Wagner M, Loy A (2011) Barcoded primers used in multiplex amplicon pyrosequencing bias amplification. Appl Environ Microbiol 77: 7846-7849.

40. Edgar RC (2010) Search and clustering orders of magnitude faster than BLAST. Bioinformatics 26: 2460-2461.

41. Bragg L, Stone G, Imelfort M, Hugenholtz P, Tyson GW (2012) Fast, accurate error-correction of amplicon pyrosequences using Acacia. Nat Methods 9: 425426.

42. Caporaso JG, Kuczynski J, Stombaugh J, Bittinger K, Bushman FD, et al. (2010) QIIME allows analysis of high-throughput community sequencing data. Nat Methods 7: 335-336.

43. Altschul SF, Madden TL, Schäffer AA, Zhang J, Zhang Z, et al. (1997) Gapped BLAST and PSI-BLAST: a new generation of protein database search programs. Nucleic Acids Res 25: 3389-3402.

44. DeSantis TZ, Hugenholtz P, Larsen N, Rojas M, Brodie EL, et al. (2006) Greengenes, a chimera-checked 16S rRNA gene database and workbench compatible with ARB. Appl Environ Microbiol 72: 5069-5072.

45. Lozupone CA, Hamady M, Kelley ST, Knight R (2007) Quantitative and qualitative beta diversity measures lead to different insights into factors that structure microbial communities. Appl Environ Microbiol 73: 1576-1585.

46. Lozupone C, Knight R (2005) UniFrac: a new phylogenetic method for comparing microbial communities. Appl Environ Microbiol 71: 8228-8235.

47. Xu Q, Almudervar A, Casey JR, Pichichero ME (2012) Nasopharyngeal bacterial interactions in children. Emerg Infect Dis 18: 1738-1745.

48. Regev-Yochay G, Dagan R, Raz M, Carmeli Y, Shainberg B, et al. (2004) Association between carriage of Streptococcus pneumoniae and Staphylococcus aureus in Children. JAMA 292: 716-720.

49. Zemlickova H, Urbaskova P, Adamkova V, Motlova J, Lebedova V, et al. (2006) Characteristics of Streptococcus pneumoniae, Haemophilus influenzae, Moraxella catarrhalis and Staphylococcus aureus isolated from the nasopharynx of healthy children attending day-care centres in the Czech Republic. Epidemiol Infect 134:1179-1187.

50. Michelow IC, Olsen K, Lozano J, Rollins NK, Duffy LB, et al. (2004) Epidemiology and clinical characteristics of community-acquired pneumonia in hospitalized children. Pediatrics 113: 701-707.

51. García-Rodríguez JA, Fresnadillo Martínez MJ (2002) Dynamics of nasopharyngeal colonization by potential respiratory pathogens. J Antimicrob Chemother 50 Suppl S2: 59-73.

52. Tenenbaum T, Franz A, Neuhausen N, Willems R, Brade J, et al. (2012) Clinical characteristics of children with lower respiratory tract infections are dependent on the carriage of specific pathogens in the nasopharynx. Eur J Clin Microbiol Infect Dis 31: $3173-3182$ 
Citation: Chappell KJ, Brealey JC, Mackay IM, Bletchly C, Hugenholtz P, et al. (2013) Respiratory Syncytial Virus Infection is Associated with Increased Bacterial Load in the Upper Respiratory Tract in Young Children. J Medical Microbiol Diagnosis S1: 005. doi:10.4172/2161-0703. S1-005

53. Bae S, Yu JY, Lee K, Lee S, Park B, et al. (2012) Nasal colonization by four potential respiratory bacteria in healthy children attending kindergarten or elementary school in Seoul, Korea. J Med Microbiol 61: 678-685.

54. Bahrani-Mougeot FK, Paster BJ, Coleman S, Barbuto S, Brennan MT, et al. (2007) Molecular analysis of oral and respiratory bacterial species associated with ventilator-associated pneumonia. J Clin Microbiol 45: 1588-1593.

55. Bogaert D, Keijser B, Huse S, Rossen J, Veenhoven R, et al. (2011) Variability and diversity of nasopharyngeal microbiota in children: a metagenomic analysis. PLoS One 6: e17035.

56. Coenye T, Goris J, Spilker T, Vandamme P, LiPuma JJ (2002) Characterization of unusual bacteria isolated from respiratory secretions of cystic fibrosis patients and description of Inquilinus limosus gen. nov., sp. nov. J Clin Microbiol 40: 2062 2069.

57. Huang YJ, Nelson CE, Brodie EL, Desantis TZ, Baek MS, et al. (2011) Airway microbiota and bronchial hyperresponsiveness in patients with suboptimally controlled asthma. J Allergy Clin Immunol 127: 372-381.

58. Kim YG, Park JH, Reimer T, Baker DP, Kawai T, et al. (2011) Viral infection augments Nod1/2 signaling to potentiate lethality associated with secondary bacterial infections. Cell Host Microbe 9: 496-507.

59. Jamieson AM, Yu S, Annicelli CH, Medzhitov R (2010) Influenza virus-induced glucocorticoids compromise innate host defense against a secondary bacterial infection. Cell Host Microbe 7: 103-114.

60. Bakaletz LO (2010) Immunopathogenesis of polymicrobial otitis media. J Leukoc Biol 87: 213-222.
61. Navarini AA, Recher M, Lang KS, Georgiev P, Meury S, et al. (2006) Increased susceptibility to bacterial superinfection as a consequence of innate antiviral responses. Proc Natl Acad Sci U S A 103: 15535-15539.

62. Hament JM, Kimpen JL, Fleer A, Wolfs TF (1999) Respiratory viral infection predisposing for bacterial disease: a concise review. FEMS Immunol Med Microbiol 26: 189-195.

63. Beadling C, Slifka MK (2004) How do viral infections predispose patients to bacterial infections? Curr Opin Infect Dis 17: 185-191.

64. Gwaltney JM Jr, Sande MA, Austrian R, Hendley JO (1975) Spread of Streptococcus pneumoniae in families. II. Relation of transfer of S. pneumoniae to incidence of colds and serum antibody. J Infect Dis 132: 62-68.

65. Nakamura S, Davis KM, Weiser JN (2011) Synergistic stimulation of type I interferons during influenza virus coinfection promotes Streptococcus pneumoniae colonization in mice. J Clin Invest 121: 3657-3665.

66. McCullers JA, McAuley JL, Browall S, Iverson AR, Boyd KL, et al. (2010) Influenza enhances susceptibility to natural acquisition of and disease due to Streptococcus pneumoniae in ferrets. J Infect Dis 202: 1287-1295.

67. Brundage JF (2006) Interactions between influenza and bacterial respiratory pathogens: implications for pandemic preparedness. Lancet Infect Dis 6: 303312 .

68. Diavatopoulos DA, Short KR, Price JT, Wilksch JJ, Brown LE, et al. (2010) Influenza A virus facilitates Streptococcus pneumoniae transmission and disease. FASEB J 24: 1789-1798.
This article was originally published in a special issue, Bacterial Pathogenecity \& Epidemiology handled by Editor. Dr. Morabito Stefano, National Institute of Health, Italy 